\title{
The Rise of Asia as a Destination for U.S. Patenting
}

\author{
Ana Maria Santacreu, Senior Economist \\ Jesse LaBelle, Research Associate
}

\section{Why Do Inventors Patent Internationally?}

To ensure that inventions are not stolen or distributed without permission, innovators seek protection using channels such as patenting. Because patents are territorial, a patent office can only guarantee protection within the borders they govern. Hence, innovators have an incentive to apply for patents in many countries. ${ }^{1}$

The growing importance of global supply chains and the increasingly interconnected world economy have led innovators to obtain protection for their intellectual property (IP) not only domestically but also internationally.

\section{What Factors Determine the Countries in Which an Inventor Seeks Protection for Their IP?}

Applying for patents in every country around the world can be very costly and unnecessary. So, inventors typically patent inventions in countries where they desire to do business. For instance, exporters of high-tech goods, especially to developing countries, may want to protect against misappropriation of the technology embodied in those goods; multinational corporations setting up affiliates abroad may want to ensure the IP they bring is protected; and firms licensing technology may want to protect their IP from potential theft. Thus, changes in the dynamics of international patenting may shed light on changes in international business dynamics. ${ }^{2,3}$

\section{Changes in International Patenting of U.S. Inventions}

In this essay, we document three features of the evolution in the patterns of international patenting of U.S. inventions between 1980 and 2019.

\section{China has become one of the} main destinations where U.S. inventors seek to protect their intellectual property.

First, U.S. patent applications substantially increased, both domestically and abroad (Figure 1), with the growth in international patenting (dashed line) outpacing that of domestic patenting (solid line) since the early 1990s. From

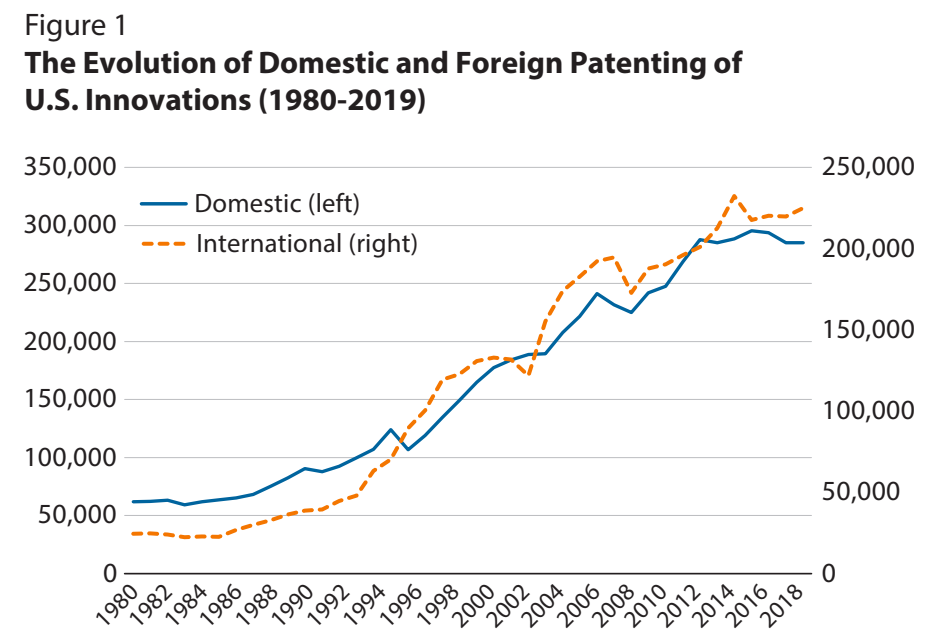

SOURCE: PATSTAT Worldwide Patent Statistical Database - EPO, World Intellectual Property Organization statistics database, and authors' calculations.

1980 to 2019, yearly domestic patent applications increased from just over 60,000 to nearly 300,000, an increase of 359 percent, while international patent applications increased from just under 25,000 to just under 225,000 , an increase of 819 percent.

Second, international patenting by U.S. inventors has shifted toward Asia (Figure 2). Prior to the establishment of the World Trade Organization (WTO) in 1995, the five nations that received the most patent applications from U.S. applicants were Canada, Brazil, Germany, South Korea, and Mexico. These nations accounted for 43 percent of these applications, with Canada alone accounting for 20.6 percent. Since the WTO, the five nations that have received the most patent applications from U.S. applicants are Japan, China, Germany, the United Kingdom, and Canada, which account for nearly 54 percent of these patents through 2019.4 Two notable changes occurred after the introduction of the WTO: (i) Before the WTO, large economies geographically close to the United States-Canada, Mexico, and Brazil-received the most patent applications from Americans. Since the WTO, however, these countries have been replaced by Japan and China. (ii) Although South Korea, Japan, and China were the only Asian countries among the top 20 recipient countries of these applications 
Figure 2

Spatial Distribution of U.S. International Patents

\section{A. $1980-94$}

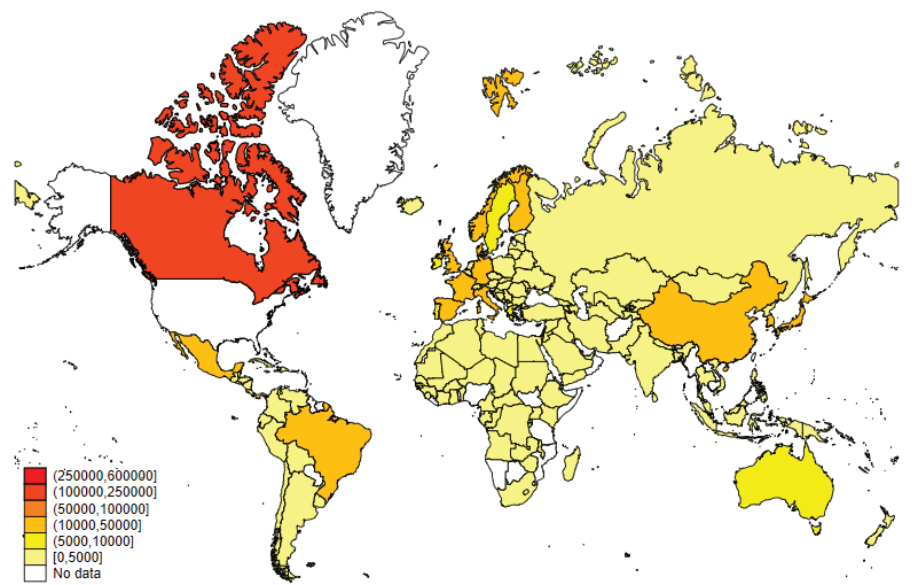

B. $1995-2019$

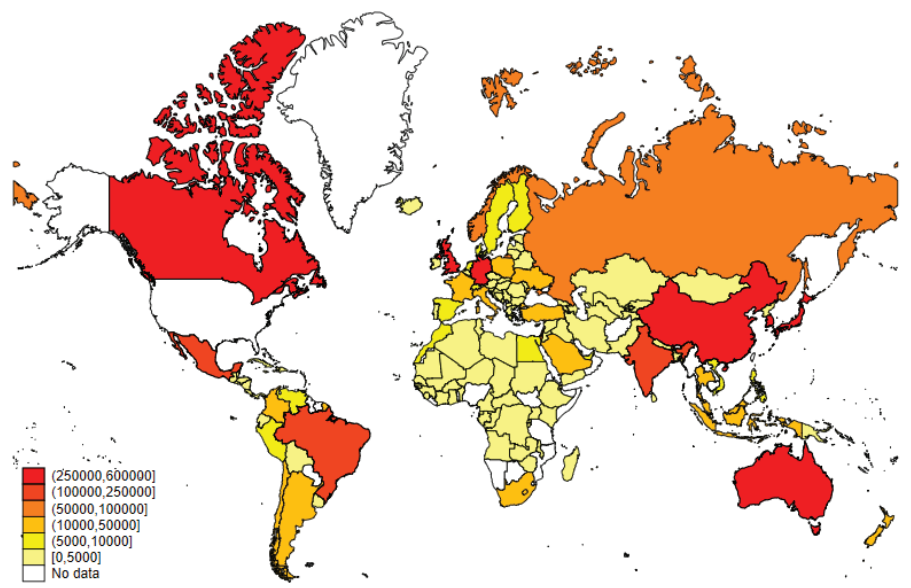

NOTE: The figure represents new patent applications of U.S inventions around the world between 1980-94 (left panel) and $1995-2019$ (right panel). The period for the second panel is longer than that for the first panel, so the numbers in the second panel will tend to be higher than in the first.

SOURCE: PATSTAT Worldwide Patent Statistical Database - EPO, World Intellectual Property Organization statistics database, and authors' calculations.

before 1995, India, Hong Kong, Singapore, Malaysia, and Thailand have joined this group since then.

Third, this shift toward Asia has focused on China, which rose from the 14th to the 2nd largest recipient of patent applications from Americans after the establishment of the WTO. In fact, China is on pace to surpass Japan (the 1st largest) within a couple of years. China is an attractive investment location, as it is the most populous country with a rapidly growing gross domestic product per capita. So, increased trade, multinational activity, and licensing with China may be increasing demand for improved IP protection through foreign patenting applications. ${ }^{5}$

\section{Conclusion}

The world economy has become more integrated, not only through trade in goods and services but also through the sharing of ideas. These trends have increased demand for cross-border IP protection. The reasons innovators seek patent protection in specific locations are still not well understood; hence, it is an important topic to study from a policy perspective.

\section{Notes}

1 In recent decades, several countries have formed regional patent alliances, such as the European Patent Office and the African Intellectual Property Organization. Demand for patenting in multiple jurisdictions has resulted in the Patent Cooperation Treaty. These agencies help expedite the process of applying to multiple jurisdictions-without having to file direct patents with each office.

2 Santacreu, Ana Maria. "Intellectual Property Rights, Technology Transfer and International Trade." Working paper, July 12, 2021; http://dx.doi.org/10.2139/ssrn.3885234.

3 Santacreu, Ana Maria. "International Technology Licensing, Intellectual Property Rights and Tax Havens." Working Paper 2019-031, Federal Reserve Bank of St. Louis, October 2020; https://doi.org/10.20955/wp.2019.031.

4 The European Patent Office would be the largest receiver if counted as one entity; however, we use a fractional distribution to spread the patents out among member direct offices proportionally, in an attempt to capture the countries in which the patents are actually being used.

5 Santacreu, Ana Maria and Jesse LaBelle. "Is China Becoming a New Innovation Powerhouse? " Federal Reserve Bank of St. Louis FRED ${ }^{\circledR}$ Blog, August 5, 2021; https://fredblog.stlouisfed.org/2021/08/is-china-becoming-a-new-innovation-powerhouse/. 